\title{
The importance of environmental factors and matrices in the adsorption, desorption, and toxicity of butyltins: a review
}

\author{
Liping Fang ${ }^{1} \cdot$ Cuihong $\mathrm{Xu}^{1} \cdot \mathrm{Ji} \mathrm{Li}^{1}$ • Ole K. Borggaard ${ }^{2}$ - Dongsheng Wang ${ }^{1,3}$
}

Received: 25 September 2016 / Accepted: 11 January 2017 / Published online: 4 February 2017

(C) Springer-Verlag Berlin Heidelberg 2017

\begin{abstract}
Butyltins (BTs) are considered as a group of the most important organometallic compounds in industry and agriculture. Due to their widespread use, large amounts of BTs including tributyltin (TBT), dibutyltin (DBT), and monobutyltin (MBT) have entered into the environment, and subsequently causing detrimental effects on humans and aquatic organisms. This work provides a critical review of recent studies on the adsorption, desorption, bioaccumulation, and toxicity of BTs that can notably influence the distribution of BTs in the environment. Influence of environmental factors (e.g., $\mathrm{pH}$ and salinity) and adsorbents in the matrices (e.g., minerals, organic carbons, and quartz) on the adsorption, desorption, and toxicity of BTs is particularly addressed.
\end{abstract}

Keywords Organotins $\cdot$ Adsorption · Desorption · Bioavailability $\cdot$ Toxicology

Responsible editor: Thomas D. Bucheli

Liping Fang

jegfang@gmail.com

$\triangle \mathrm{Ji} \mathrm{Li}$

841594275@qq.com

1 Department of Chemistry, Faculty of Material Sciences and Chemistry, China University of Geosciences, Wuhan 430074, China

2 Department of Plant and Environmental Sciences, University of Copenhagen, Thorvaldsensvej 40, DK-1871 Frederiksberg C, Denmark

3 State Key Laboratory of Environmental Aquatic Chemistry, Research Center for Eco-Environmental Sciences, Chinese Academy of Sciences, Beijing 100085, China

\section{Introduction}

As one of the most important organometallic compounds, butyltins (BTs) such as tributyltin (TBT), dibutyltin (DBT), and monobutyltin (MBT) have been widely used as additives of antifouling paints, biocides, and stabilizers (Fent 1996; Hoch 2001). Due to wide commercial applications, large amounts of BTs have been released into the ecosystems, and high levels of BTs have also been observed in freshwater systems and wastewater treatment plants (Bartlett et al. 2004; Sabah et al. 2016). The observation of causing sexual abnormality in gastropod mollusks (Nucella lapillus) and unnatural shell calcification in oysters by TBT has been receiving intense public attention, and consequently leading to its first legislation (Matthiessen and Gibbs 1998). More and more evidences have shown that BTs cause a significant reduction in the development, reproduction, and survival of many marine species (Frouin et al. 2008; Giraud-Billoud et al. 2013; Gumy et al. 2008; Lopes-dos-Santos et al. 2014). Of all butyltins, TBT presents the highest toxicity to aquatic organisms, by disturbing the function of mitochondria, while DBT and MBT are less toxic. However, DBT is reported to decrease lymphocyte proliferation of seals more than the other BTs (Frouin et al. 2008). The worldwide prohibition on the use of TBT came into effect in 2003 by the International Marine Organization (IMO), and the application of TBT-based antifouling paints has been totally phased out by 2008 (IMO 2005). However, no restriction has been implemented for DBT and MBT to date.

In spite of the restrictive regulation of TBT by the IMO, high concentration BTs still can be detected at high levels in many countries particularly from Asia and South America (Choi et al. 2013; Castro et al. 2012; Del Brio et al. 2016; Ho and Leung 2014; Paz-Villarraga et al. 2015). Adsorption and desorption processes of BTs by environmental matrices such as sediments and minerals play an important role in their levels in different 
environmental matrices, and consequently affecting the bioavailability and toxicity of BTs in the environment (Burton et al. 2004; Gao et al. 2015; Hoch 2001; Fang et al. 2010, 2012). Studies have also shown that the adsorption and desorption processes of BTs are highly dependent on the property of matrices. For example, Fang and coworkers reported that black carbons (BCs) as an important fraction of organic carbon can significantly contribute to the overall adsorption of BTs, consequently leading to overestimated toxicity of BTs to organisms (Fang et al. 2010, 2011). In addition, environmental factors such as $\mathrm{pH}$ and salinity can remarkably influence BT adsorption and desorption processes and their bioaccumulation and toxicity. Weidenhaupt et al. (1997) studied the adsorption of TBT to minerals at different $\mathrm{pHs}$, showing that the adsorption of TBT was strongly $\mathrm{pH}$ dependent. The similar findings have also been reported for DBT and MBT (Fang et al. 2012; Hoch et al. 2003).

Considering the importance of environmental factors and matrices in the bioavailability and toxicity of BTs in the environment, this work briefly reviews the physicochemical property, application, and distribution of BTs. In particular, this review focuses on recent studies on the adsorption, desorption, toxicology, and bioaccumulation of BTs by emphasizing the effect of environmental conditions (e.g., $\mathrm{pH}$ and salinity) and matrices (e.g., minerals, BCs).

\section{Properties, application, and distribution of BTs}

BTs comprise a group of organometallic moieties, where the Sn atom is covalently bound to at least one organic group, such as alkyl and phenyl groups (Hoch 2001). Generally, BTs can be expressed by the formula $R_{n} \mathrm{Sn} X_{4-n}$ ( $R$ denotes organic group; $X$ denotes anionic group such as halide and hydroxide).

\section{Synthesis and applications of BTs}

According to the formula $R_{n} \operatorname{Sn} X_{4-n}$, BTs comprise four compounds including tetrabutyltin (TeBT), TBT, DBT, and MBT. The main properties of the four BTs are listed in Table 1. TeBT as a precursor of the other BTs can be directly produced from $\mathrm{SnCl}_{4}$ using a Grignard method (Peter 2003).

Table 1 Physicochemical properties of tetrabutyltin (TeBT), tributyltin chloride (TBT), dibutyltin dichloride (DBT), and monobutyltin trichloride (MBT)

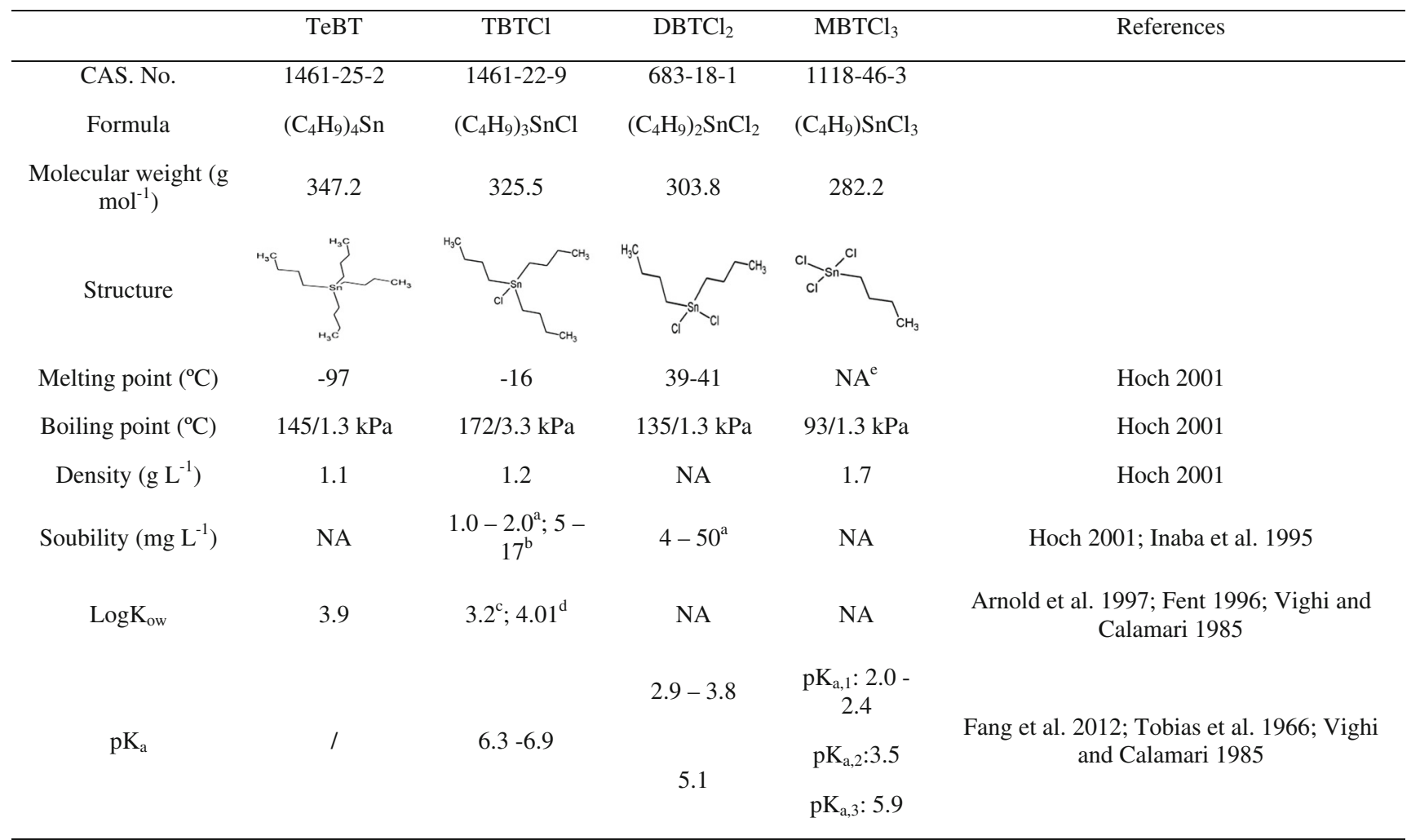

\footnotetext{
NA not available

${ }^{\text {a }}$ Solubility in seawater

${ }^{\mathrm{b}}$ Solubility in distilled water

${ }^{\mathrm{c}} \mathrm{TBT}$ in Tris- $\mathrm{HCl}$ buffer at $\mathrm{pH} 6$

${ }^{\mathrm{d}} \mathrm{TBT}$ in $10 \mathrm{mM} \mathrm{NaClO}_{4}$ at $\mathrm{pH} 8$
} 
$4 \mathrm{BuMgX}+\mathrm{SnCl}_{4} \rightarrow \mathrm{Bu}_{4} \mathrm{Sn}+4 \mathrm{MgClX}$

The Grignard reagent, $\mathrm{BuMgX}$, acts as nucleophile and attacks the electrophilic Sn atoms, consequently yielding a polar bond between carbon and tin atoms.

By further reaction with tin(IV) chloride, other BTs can be formed as exemplified by the TBT formation.

$3 \mathrm{Bu}_{4} \mathrm{Sn}+\mathrm{SnCl}_{4} \rightarrow 4 \mathrm{Bu}_{3} \mathrm{SnCl}$

The Sn-C bond is considered to be stable in water and the atmosphere and can resist heating (up to $200^{\circ} \mathrm{C}$ ), whereas UV radiation and biological activity can lead to debutylation (Hoch 2001; Peter 2003).

BTs have been applied for different purposes in the agricultural and industrial fields for decades, and their main application is listed in Table 2. TBT is used as biocide for antifouling paint and wood protection, while DBT and MBT are used as stabilizer additives in PVC products and polyurethane. TeBT is mainly used as precursor of the other BTs (i.e., TBT, DBT, and MBT).

\section{Speciation of BTs}

Knowledge about speciation is essential for understanding the chemistry of BTs in aqueous solutions and, hence, their environmental fate, bioavailability, and toxicity (Fent 1996). Several studies have found that the speciation of BTs (except TeBT) depends on the $\mathrm{pH}$ and anions in aqueous solutions (Arnold et al. 1997; Fent 1996; Weidenhaupt et al. 1997). It shows that TBT, DBT, and MBT can undergo hydrolysis in aqueous solutions (Table 3). These BTs are expected to be positively charged at low $\mathrm{pH}$ and predominate in neutral forms at $\mathrm{pH}>7$ (ionic strength $10 \mathrm{mM} \mathrm{NaClO}_{4}$ ) (Arnold et al. 1997; Hoch 2001). The acidity constant $\left(\mathrm{pK}_{\mathrm{a}}\right)$ value of TBT is found to be 6.3 , estimated by potentimetric titration (Shoukry 1996), or 6.9 by modeling (Arnold et al. 1997; Vighi and Calamari 1985). Thus, at $\mathrm{pH}<6.5,\left(\mathrm{C}_{4} \mathrm{H}_{9}\right)_{3} \mathrm{Sn}^{+}\left(\mathrm{TBT}^{+}\right)$dominates in water, whereas the neutral species $\left.\mathrm{C}_{4} \mathrm{H}_{9}\right)_{3} \mathrm{Sn}-\mathrm{OH}(\mathrm{TBTOH})$ is predominant at $\mathrm{pH}>6.5$ (Fig. 1). This has also been confirmed by ${ }^{119} \mathrm{Sn}$ nuclear magnetic resonance (Hynes and Odowd 1985) and Mössbauer spectroscopy (Eng et al. 1986).

DBT and MBT are expected to have two or three hydrolysis steps and hence two or three $\mathrm{pK}_{\mathrm{a}}$ values, respectively. By potentiometric titration, estimated values of $\mathrm{pK}_{\mathrm{a}, 1}$ of 3.0 and $\mathrm{pK}_{\mathrm{a}, 2}$ of 5.1 were found for DBT and $\mathrm{pK}_{\mathrm{a}, 1}$ of $2.3, \mathrm{pK}_{\mathrm{a}, 2}$ of 3.5 and $\mathrm{pK}_{\mathrm{a}, 3}$ of 5.9 for MBT (Table 2; Fang et al. 2012). These values are in good agreement with the findings (e.g., $\mathrm{pK}_{\mathrm{a}, 1}=3.8$ and 2.0 for DBT and MBT) by Vighi and Calamari (1985) and Shoukry (1996). According to the $\mathrm{pK}_{\mathrm{a}}$ values, MBT and DBT mainly exist as a mixture of dicharged (i.e., $\mathrm{MBT}(\mathrm{OH})^{2+}$ and $\mathrm{DBT}^{2+}$ ) and monocharged species (i.e., $\operatorname{MBT}(\mathrm{OH})_{2}{ }^{+}$and $\left.\mathrm{DBT}(\mathrm{OH})^{+}\right)$at $\mathrm{pH}<4$. In the $\mathrm{pH}$ range of 4 to 6 , they dominate as monocharged species and as neutral species (i.e., $\mathrm{MBT}(\mathrm{OH})_{3}$ and $\mathrm{DBT}(\mathrm{OH})_{2}$ ) at $\mathrm{pH}>6$ (Fig. 1).

In addition, the dissociation reactions of BTs are influenced by temperature, ionic strength, and anionic composition (Fent 1996). In particular, ionic strength is highly related with salinity in marine and estuarine systems, which can determine the species of BTs. Studies show that the neutral TBTCl species account for $36-68 \%$ of total TBT in seawater at $\mathrm{pH}<6$ and even $2-3 \%$ of total TBT at $\mathrm{pH} 8$ (formation constant of TBTCl, $\log \mathrm{K}_{\mathrm{i}}=0.6$ ) (Arnold et al. 1997; Burton et al. 2004). However, there is limited knowledge on the effect of salinity on the species of MBT and DBT, which should be further explored in future work.

\section{BTs in different matrices}

Due to their widespread applications, BTs have been found in many different matrices such as surface water, sediment/soil, and various organisms from different regions (Choi et al. 2009; Del Brio et al. 2016; Castro et al. 2012; Ho and Leung 2014; Jacobsen and Asmund 2000; Paz-Villarraga et al. 2015; Tang and Wang 2009). Comprehensive reviews on the occurrence and environmental levels of BTs in different regions have been well documented by other researchers such as AntizarLadislao (2008) and Sousa et al. (2014). This work emphasizes on the importance of environmental factors and matrices in the adsorption, desorption, bioaccumulation, and toxicity of BTs; hence, a few typical examples are summarized to show

Table 2 The hydrolytic reactions of butyltins (BTs) in water

\begin{tabular}{|c|c|c|c|}
\hline Butyltin & Hydrolysis process & $\mathrm{pK}_{\mathrm{a}}$ & Reference \\
\hline TBT & $\mathrm{TBT}^{+}+\mathrm{H}_{2} \mathrm{O} \rightleftarrows \mathrm{TBTOH}+\mathrm{H}^{+}$ & $6.3 \pm 0.1^{\mathrm{a}}$ & Arnold et al. (1997) \\
\hline DBT & $\begin{array}{l}\mathrm{DBT}^{2+}+\mathrm{H}_{2} \mathrm{O} \rightleftarrows \mathrm{DBT}(\mathrm{OH})^{+}+\mathrm{H}^{+} \\
\mathrm{DBT}(\mathrm{OH})^{+}+\mathrm{H}_{2} \mathrm{O} \rightleftarrows \mathrm{DBT}(\mathrm{OH})_{2}+\mathrm{H}^{+}\end{array}$ & $\begin{array}{l}3.0 \pm 0.1 \\
5.1 \pm 0.2\end{array}$ & Fang et al. (2012) \\
\hline MBT & $\begin{array}{l}\mathrm{MBT}^{3+}+\mathrm{H}_{2} \mathrm{O} \rightleftarrows \mathrm{MBT}(\mathrm{OH})^{2+}+\mathrm{H}^{+} \\
\mathrm{MBT}^{2+}+\mathrm{H}_{2} \mathrm{O} \rightleftarrows \operatorname{MBT}(\mathrm{OH})_{2}^{+}+\mathrm{H}^{+} \\
\operatorname{MBT}(\mathrm{OH})_{2}^{+}+\mathrm{H}_{2} \mathrm{O} \leftrightarrow \operatorname{MBT}(\mathrm{OH})_{3}+\mathrm{H}^{+}\end{array}$ & $\begin{array}{l}2.3 \pm 0.1 \\
3.5 \pm 0.2 \\
5.9 \pm 0.1\end{array}$ & Fang et al. (2012) \\
\hline
\end{tabular}

${ }^{a}$ Value given as average \pm standard deviation 
Table 3 Application of butyltins (BTs)

\begin{tabular}{llll}
\hline Butyltin & Application & Main use & Reference \\
\hline MBT & Catalyst & Industrial processes & Hoch (2001), WHO (1990) \\
& Oxide films on glass & Glass treatment & \\
SBT & Stabilization against heat and light & PVC stabilizer & Hoch (2001), Peter (2003) \\
& Catalyst & Polyurethane & \\
SBT & Stabilizers & PCV and plastics stabilizer & Hoch (2001), WHO (1990) \\
& Mewormer & Poultry farming & \\
TeBT & Insecticide, fungicide & Agrochemicals & \\
\hline
\end{tabular}
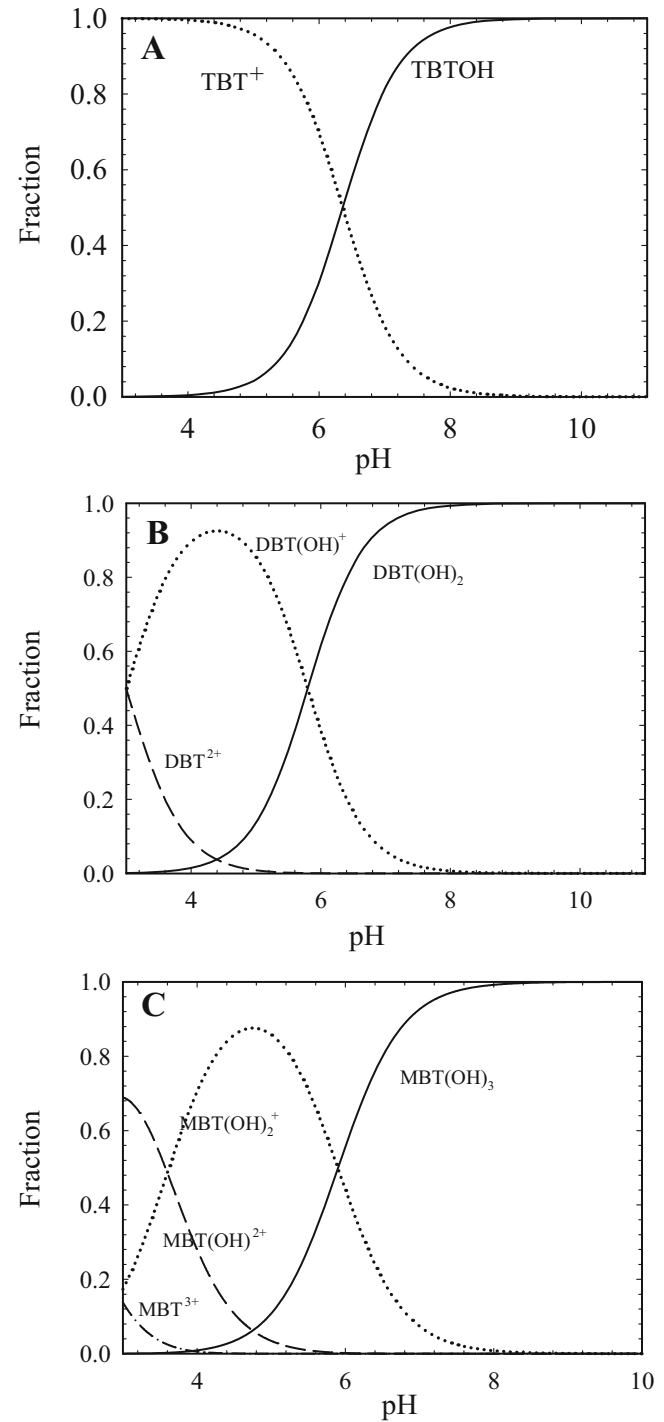

Fig. 1 Speciation of TBT (a), DBT (b), and MBT (c) as a function of $\mathrm{pH}$, respectively. The TBT species distribution as a function of $\mathrm{pH}$ is calculated according to $\mathrm{pK}_{\mathrm{a}}$ of 6.3 (Arnold et al. 1997), while for DBT and MBT, they are calculated on the basis of $\mathrm{pK}_{\mathrm{a}}$ values by Fang et al. (2012) the BT distributions in various environmental matrices of different countries (Table 4). The concentrations of the three BTs exhibit a great variation in the different matrices and from place to place. High concentrations of BTs can still be detected in sediments and organisms of marine systems in South America according to the findings by Castro and coworkers (Del Brio et al. 2016; Laitano et al. 2015; Paz-Villarraga et al. 2015). The high content of BTs in marine sediments observed after the worldwide ban reflects the persistence of BTs in sediments and organisms (Strand et al. 2003, 2005). The enrichment of BTs in sediments can be due to the high distribution coefficients $\left(K_{\mathrm{d}}\right)$ of BTs ranging from $10^{2}$ to $10^{6} \mathrm{~L} \mathrm{~kg}^{-1}$ in natural adsorbents such as organic matters and clay minerals (Burton et al. 2004), and high content of BTs in organisms is due to the high bioconcentration factor (BAF) values of TBT in bivalves ranging from about 16,000 to 400,000 (Tang and Wang 2008). On the other hand, adsorption to sediment and bioaccumulation in organisms can slow down the degradation of BTs from a few weeks to decades, which poses a threat to human and ecosystem (Nielsen and Strand 2002; Craig 2003; Peter 2003; Tang and Wang 2008).

\section{Adsorption of BTs}

Adsorption behavior is considered to be an important process affecting the transport, bioavailability, and toxicity of BTs in the environment (Weber et al. 1991). Studies on the adsorption of BTs to different matrices have been widely reported. These matrices include clays (Hermosin et al. 1993; Hoch et al. 2003; Weidenhaupt et al. 1997), quartz (Behra et al. 2003; Bueno et al. 1998), amorphous silica (Weidenhaupt et al. 1997), metal oxides (Randall and Weber 1986; Weidenhaupt et al. 1997), organic matters (Arnold et al. 1998; O'Loughlin et al. 2000; Said-Pullicino and Vella 2005), BCs (Brandli et al. 2009; Fang et al. 2010, 2012), natural soils, and sediments (Burton et al. 2004; Burton et al. 2006; Huang and Matzner 2004). Studies have demonstrated 
Table 4 Selected studies on butyltin (BT) distribution in water, sediment, and organisms

\begin{tabular}{|c|c|c|c|c|c|c|}
\hline \multirow[t]{2}{*}{ Sample } & \multirow[t]{2}{*}{ Location } & \multirow[t]{2}{*}{ Year } & \multicolumn{3}{|c|}{ Level of BTs } & \multirow[t]{2}{*}{ Reference } \\
\hline & & & TBT & DBT & MBT & \\
\hline \multicolumn{7}{|c|}{ Water (ng Sn L ${ }^{-1}$ ) } \\
\hline & \multirow[t]{2}{*}{ Korean coastal area } & $2001-2003$ & $<$ d.1.-164 & $<$ d.l. & $<$ d.l. & Choi et al. (2009) \\
\hline & & 2004-2005 & $<$ d.1.-24 & $<$ d.l. & $<$ d.l. & Choi et al. (2009) \\
\hline & Estuary stream, Taiwan & 2009 & $0.6-39.6$ & $1.0-47.5$ & $6.8-96$ & Tang and Wang (2009) \\
\hline \multicolumn{7}{|c|}{ Sediments (ng Sn $\mathrm{g}^{-1}$ ) } \\
\hline & Korean coasts & $2001-2003$ & $<$ d.1.-9576 & $<$ d.l. & $<$ d.1. & Choi et al. (2009) \\
\hline & Crystal Lake, USA & $2001-2003$ & $1.5-14,000$ & $59-350$ & $21.3-320$ & Landmeyer et al. (2004) \\
\hline & Estuary, Taiwan & 2009 & $9-194$ & $4-107$ & $26-238$ & Tang and Wang (2009) \\
\hline & Sanricu Coast, Japan & 2005 & $2-14,000$ & $<$ d.1. -3400 & $<$ d.1. -3300 & Harino et al. (1998) \\
\hline & Northwest Coast, Spain & 2005 & $0.6-303$ & $0.5-357$ & $0.7-3.8$ & Üveges et al. (2007) \\
\hline & Concepción, Chile & 2013 & $1.2-122$ & $4.7-103$ & $3.1-118$ & Batista et al. (2016) \\
\hline & Mar del Plata coast, Argentina & 2012 & $<2-150$ & $<3-12$ & $<0.9-259$ & Laitano et al. (2015) \\
\hline & Caribbean Sea, Venezuela & 2015 & 84-1929 & $15-990$ & $12-456$ & Paz-Villarraga et al. (2015) \\
\hline \multicolumn{7}{|c|}{ Organisms (ng Sn $\mathrm{g}^{-1}$ ) } \\
\hline Bivalves & Korean coasts & $2001-2003$ & $20-6296$ & $<$ d.l. & $<$ d.1. & Choi et al. (2009) \\
\hline Oyster & Estuary, Taiwan & 2009 & $26-1071$ & $10-957$ & $4-1215$ & Tang and Wang (2009) \\
\hline Mussel & Sanricu Coast, Japan & 2005 & $3-287$ & $3-92$ & $4-32$ & Harino et al. (1998) \\
\hline Mussel & Northwest Coast, Spain & 2005 & $52.8-96.1$ & $20-25.7$ & $52-96$ & Üveges et al. (2007) \\
\hline Human liver & Denmark & 1999-2000 & $<$ d.1. -0.3 & $0.8-28.3$ & $0.6-4.7$ & Nielsen and Strand (2002) \\
\hline Gastropod & Valparaíso, Chile & 2013 & $7.4-15.8$ & $27.4-574.3$ & $11.6-68.8$ & Batista et al. (2016) \\
\hline Mussel & Caribbean Sea, Venezuela & 2015 & $<$ d.1. -43.2 & $<$ d.1.-13.5 & $<$ d.1. -53.6 & Paz-Villarraga et al. (2015) \\
\hline
\end{tabular}

d.l. detection limit

that the environmental factors (e.g., $\mathrm{pH}$ and salinity) and property of matrices can significantly affect the adsorption of BTs. In this section, the importance of these environmental factors and matrices in the adsorption of BTs is highlighted. In addition, the competitive adsorption and adsorption mechanism of BTs to different matrices is addressed.

\section{Effects of environmental factors}

\section{Temperature}

Temperature is an important factor that reflects the change of season (e.g., from winter to summer) and region (e.g., from high to low latitude region). Variation of BTs in sediment/soil has been observed in the literature due to the variable temperature and geological conditions (Quintas et al. 2016). However, only a few studies have been undertaken with respect to the effect of temperature on the adsorption of TBT to sediments. Bangkedphol et al. (2009) found that the distribution coefficient $\left(K_{\mathrm{d}}\right)$ of TBT between seawater $(\mathrm{pH} 8)$ and marine sediment (Bowling Basin, UK) significantly increases from $3981 \mathrm{~L} \mathrm{~kg}^{-1}$ at $20^{\circ} \mathrm{C}$ to $5012 \mathrm{~L} \mathrm{~kg}^{-1}$ at $40{ }^{\circ} \mathrm{C}$. A similar trend of TBT adsorption to estuarine sediment was also observed by Ma et al. (2000), showing an increased $K_{\mathrm{d}}$ from 7511 to $8862 \mathrm{~L} \mathrm{~kg}^{-1}$ from 25 to $35^{\circ} \mathrm{C}$. These findings may suggest that higher temperature favors the adsorption of BTs to sediments, which can affect the bioavailability of BTs in the environment.

\section{Salinity}

Salinity is an important environmental factor in estuarine, saline lake, and marine systems. Studies have demonstrated that salinity can alter the solubility, octane/water partition coefficient $\left(K_{\mathrm{ow}}\right)$ of BTs, as well as the ionic strength in solution (Laughlin et al. 1986; Inaba et al. 1995; Ni et al. 2000), and subsequently, salinity can influence the environmental behavior of BTs in the environment. A number of studies have shown that salinity can affect the BT adsorption (Table 5; Randall and Weber 1986; Unger et al. 1988; Burton et al. 2004; Hoch et al. 2002). In general, four different ways (i.e., types I, II, III, and IV) of salinity effect on the BT adsorption can be summarized according to Table 5 (Fig. 2).

Hoch (2004) observed a trend of type I for TBT adsorption to kaolinite from salinity of 0 to 32 at $\mathrm{pH} 4$, where the predominant TBT species is positively charged $\mathrm{TBT}^{+}$(Fig. 1). 
Table 5 Summary of the experimental conditions collected from the literature for the determination of butyltin (BT) adsorption as a function of salinity

\begin{tabular}{|c|c|c|c|c|}
\hline Butyltin & Adsorbent & Experimental condition & Result & Reference \\
\hline \multirow[t]{9}{*}{ TBT } & $\begin{array}{l}\text { Mixture of Fe-hydroxides } \\
\text { and fulvic acid }\end{array}$ & $\begin{array}{l}\text { TBT initial concentration } 10 \mathrm{mg} \mathrm{L}^{-1} \\
\text { (as } \mathrm{Sn} \text { ); mixture of } \\
10-1000 \mathrm{mg} \mathrm{L}^{-1} \text { Fe-hydroxide } \\
\text { and } 10 \mathrm{mg} \mathrm{L}^{-1} \text { fulvic acid; } \mathrm{pH} \\
6.2-8.2\end{array}$ & $\begin{array}{l}\text { The adsorption of TBT increases } \\
\text { with increasing salinity from } 0 \\
\text { to } 3 \% \text { (type II) }\end{array}$ & $\begin{array}{l}\text { Randall and Weber } \\
\text { (1986) }\end{array}$ \\
\hline & Natural sediments & $\begin{array}{l}60 \mathrm{mg} \mathrm{L}^{-1} \text { of sediments in solution; } \\
\mathrm{pH} 8\end{array}$ & & $\begin{array}{l}\text { Harris and Cleary } \\
\text { (1987) }\end{array}$ \\
\hline & Natural sediment & $100 \mathrm{~g} \mathrm{~L}^{-1}$ of sediment; $\mathrm{pH} 8$ & & Burton et al. (2004) \\
\hline & Natural sediments & $17 \mathrm{~g} \mathrm{~L}^{-1}$ of sediments & $\begin{array}{l}\text { The adsorption of TBT decreases } \\
\text { with increasing salinity from } 0 \\
\text { to } 3 \% \text { (type IV) }\end{array}$ & Unger et al. (1988) \\
\hline & Natural sediments & $100 \mathrm{~g} \mathrm{~L}^{-1}$ of sediment; $\mathrm{pH} 4$ & & Burton et al. (2004) \\
\hline & Montmorillonite & $\begin{array}{l}\text { Initial concentration of TBT was } 400 \\
\text { and } 1000 \mu \mathrm{g} \mathrm{L}^{-1} \text { (as Sn); } \mathrm{pH} 8\end{array}$ & & Hoch et al. (2002) \\
\hline & $\begin{array}{l}\text { Montmorillonite or } \\
\text { kaolinite }\end{array}$ & $\begin{array}{l}\text { TBT initial concentration was } \\
400 \mu \mathrm{g} \mathrm{L}^{-1} \text { (as Sn); } \mathrm{pH} 6\end{array}$ & & $\begin{array}{l}\text { Hoch (2004), Hoch and } \\
\text { Schwesig (2004) }\end{array}$ \\
\hline & Natural sediments & $\begin{array}{l}100 \mathrm{~g} \mathrm{~L}^{-1} \text { of sediments; the initial } \\
\text { concentration of TBT was } \\
4 \mathrm{mg} \mathrm{L}^{-1} \text { (as Sn); pH } 7.9\end{array}$ & $\begin{array}{l}\text { No significant change of } \\
\text { adsorption with increasing } \\
\text { salinity from } 0 \text { to } 3 \% \text { (type I) }\end{array}$ & Ma et al. (2000) \\
\hline & Kaolinite & $\begin{array}{l}\text { TBT initial concentration } \\
\qquad 400 \mu \mathrm{g} \mathrm{L}^{-1} \text { (as Sn); } \mathrm{pH} 4\end{array}$ & & Hoch (2004) \\
\hline \multirow[t]{2}{*}{ Butyltin } & Kaolinite & $\begin{array}{l}\text { Initial concentration of TBT } \\
400 \mu \mathrm{g} \mathrm{L}^{-1} \text { (as Sn); } \mathrm{pH} 8\end{array}$ & $\begin{array}{l}\text { The adsorption of TBT decreases } \\
\text { with increasing salinity from } 0 \\
\text { to } 2-2.5 \% \text { and then increases } \\
\text { with increasing salinity from } \\
2.5-10 \% \text { (type III). }\end{array}$ & Hoch (2004) \\
\hline & Sediments & $\begin{array}{l}\text { Initial concentration of TBT } \\
6-6000 \mathrm{ng} \mathrm{L}^{-1} \text { (as TBT); } \\
1.3 \mathrm{~g} \mathrm{~L}^{-1} \text { sediments; } \mathrm{pH} 8\end{array}$ & & $\begin{array}{l}\text { Langston and Pope } \\
\text { (2001) }\end{array}$ \\
\hline \multirow[t]{3}{*}{ DBT } & Montmorillonite sediments & $\begin{array}{l}\text { DBT initial concentration } \\
\quad 100-1000 \mu \mathrm{g} \mathrm{L}^{-1} \text { (as Sn); } \mathrm{pH} 8\end{array}$ & $\begin{array}{l}\text { The adsorption of DBT decreases } \\
\text { with increasing salinity from } 0 \\
\text { to } 3.2 \% \text { (type IV) }\end{array}$ & Hoch et al. (2003) \\
\hline & $\begin{array}{l}\text { Mixture of Fe-hydroxides } \\
\text { and fulvic acid }\end{array}$ & $\begin{array}{l}10 \mathrm{mg} \mathrm{L}^{-1} \text { (as Sn) DBT; the mixture } \\
\text { of } 10 \mathrm{mg} \mathrm{L}^{-1} \text { of Fe-hydroxides } \\
\text { and } 10 \mathrm{mg} \mathrm{L}^{-1} \text { of fulvic acid; } \mathrm{pH} \\
8\end{array}$ & & $\begin{array}{l}\text { Randall and Weber } \\
\text { (1986) }\end{array}$ \\
\hline & $\begin{array}{l}\text { Mixture of Fe-hydroxides } \\
\text { and fulvic acid }\end{array}$ & $\begin{array}{l}10 \mathrm{mg} \mathrm{L}^{-1} \text { (as Sn) DBT; mixture of } \\
1000 \mathrm{mg} \mathrm{L}^{-1} \text { of Fe-hydroxides } \\
\text { and } 10 \mathrm{mg} \mathrm{L}^{-1} \text { of fulvic acid; } \mathrm{pH} \\
8 \text { and } 6\end{array}$ & $\begin{array}{l}\text { The adsorption of DBT increases } \\
\text { with increasing salinity from } 0 \\
\text { to } 3.2 \% \text { (type II). }\end{array}$ & $\begin{array}{l}\text { Randall and Weber } \\
\text { (1986) }\end{array}$ \\
\hline \multirow[t]{2}{*}{ MBT } & $\begin{array}{l}\text { Mixture of Fe-hydroxides } \\
\text { and fulvic acid }\end{array}$ & $\begin{array}{l}10 \mathrm{mg} \mathrm{L}^{-1} \text { (as Sn) MBT; mixture of } \\
10 \mathrm{mg} \mathrm{L}^{-1} \text { of Fe-hydroxides and } \\
10 \mathrm{mg} \mathrm{L}^{-1} \text { of fulvic acid; } \mathrm{pH} 8 \\
\text { and } 6\end{array}$ & $\begin{array}{l}\text { The adsorption of MBT } \\
\text { decreases with increasing } \\
\text { salinity from } 0 \text { to } 3.2 \% \text { (type } \\
\text { IV) }\end{array}$ & $\begin{array}{l}\text { Randall and Weber } \\
\text { (1986) }\end{array}$ \\
\hline & $\begin{array}{l}\text { Mixture of Fe-hydroxides } \\
\text { and fulvic acid }\end{array}$ & $\begin{array}{l}10 \mathrm{mg} \mathrm{L}^{-1} \text { (as Sn) MBT; mixture of } \\
1000 \mathrm{mg} \mathrm{L}^{-1} \text { of Fe-hydroxides } \\
\text { and } 10 \mathrm{mg} \mathrm{L}^{-1} \text { of fulvic acid; } \mathrm{pH} \\
8 \text { and } 6\end{array}$ & $\begin{array}{l}\text { No significant change of the } \\
\text { MBT adsorption with } \\
\text { increasing salinity from } 0 \text { to } \\
3.2 \% \text { (type I) }\end{array}$ & $\begin{array}{l}\text { Randall and Weber } \\
\text { (1986) }\end{array}$ \\
\hline
\end{tabular}

The authors suggest that the zero point charge $\left(\mathrm{pH}_{\mathrm{zpc}}\right)$ of 4.9 for kaolinite is the determinant factor for the adsorption of TBT (Hoch 2004).

Harris and Cleary (1987) observed a sigmoidal trend (type II) for the adsorption of TBT to sediments at $\mathrm{pH} 8$, showing an increasing TBT adsorption with the increase of salinity from 0 to 30. A similar trend was found for DBT adsorption to a mixture of iron hydroxides and fulvic acid at pH 8 (Randall and Weber 1986). The type II adsorption trend can be due to "salting out" effect that increases the adsorption of neutral TBT and DBT species at pH 8. However, Ma et al. (2000) observed an adsorption trend of type I for adsorption of TBT to natural sediment at $\mathrm{pH} 7.9$ by increasing the salinity up to 30 , showing no significant salting out effect on the adsorption of neutral TBT species. This may be due to that salting out effect highly depends on the content of organic matter (Ma 


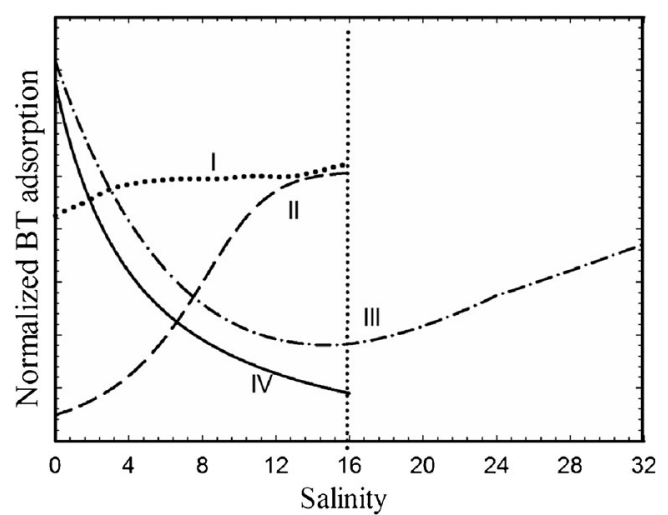

Fig. 2 Four types of schematic tendencies for the adsorption of TBT as a function of salinity (type I, II, III, and IV). The four types of tendencies are summarized according to the data from the literature listed in Table 5

et al. 2000). Inversely, by increasing salinity from 0 to 32 , the adsorption of TBT to kaolinite or montmorillonite at $\mathrm{pH} 8$ decreases from 0 to 15 but then increases with further increasing salinity from 15 to 32 as shown as type III (Hoch 2004; Langston and Pope 2001). Because TBT predominates as neutral form at $\mathrm{pH} 8$, there should be no competitive adsorption to minerals from background cations. However, the exact mechanism of type III adsorption for TBT is still not clear by far.

On the other hand, a trend of type IV was found for the adsorption of TBT to sediment at $\mathrm{pH} 4$ and 6 , showing that
TBT adsorption decreased by increasing salinity from 0 to 30 (Unger et al. 1988). This was also observed at the same $\mathrm{pH}$ range by Burton et al. (2004). As TBT mainly presents as cationic $\mathrm{TBT}^{+}$species at $\mathrm{pH}<6$, the strong competitive adsorption from background cations with positively charged TBT with the increase of salinity from 0 to 30 leads to a reduced TBT adsorption (Burton et al. 2004).

$p H$

$\mathrm{pH}$ can affect the speciation of BTs and the surface chemistry of adsorbents that carry dissociable functional groups, as a result, influencing the adsorption of BTs (Arnold et al. 1998; Burton et al. 2004; Fang et al. 2010, 2012; Hoch and Schwesig 2004; Hoch et al. 2003; Hunziker et al. 2001).

Representative findings of the $\mathrm{pH}$ effect on the BT adsorption by various adsorbents under different experimental conditions are summarized in Table 6. Studies show that the adsorption of TBT consistently increases with increasing $\mathrm{pH}$ from acidic to neutral condition but dramatically decreases with the further increasing $\mathrm{pH}$ to an alkaline condition (Table 6). However, Fang et al. (2010) reported that the adsorption of TBT to soot keeps constantly from neutral to alkaline condition. This inconsistent finding is ascribed to the absence of functional group upon the surface of soot that is

Table 6 The pH effect on the adsorption of butyltins (BTs) to adsorbents

\begin{tabular}{|c|c|c|c|c|}
\hline Butyltin & Adsorbent & Media & Result & Reference \\
\hline \multirow[t]{11}{*}{ TBT } & Municipal solid water & Seawater & \multirow{10}{*}{$\begin{array}{l}\text { Adsorption of TBT increases from } \\
\mathrm{pH} 4 \text { to } 7 \text {, and then decreases at } \\
\text { higher } \mathrm{pH} \text {. }\end{array}$} & Sai-Pullicino and Vella (2005) \\
\hline & Montmorillonite & Deionized water; $3.2 \%$ seawater & & Hoch and Schwesig (2004) \\
\hline & Sediment & Freshwater and seawater & & Bangkedphol et al. (2009) \\
\hline & Humic acid & $10 \mathrm{mM} \mathrm{NaClO}_{4}$ & & Arnold et al. (1998) \\
\hline & Quartz & $0.1 \mathrm{M} \mathrm{NaNO}_{3}$ & & Bueno et al. (1998) \\
\hline & Amorphous $\mathrm{SiO}_{2}$ & $10 \mathrm{mM} \mathrm{NaClO}_{4}$ & & Weidenhaupt et al. (1997) \\
\hline & Kaolinite & $10 \mathrm{mM} \mathrm{NaClO}_{4}$ & & Weidenhaupt et al. (1997) \\
\hline & Marine sediment & Seawater & & Langston and Pope (1995) \\
\hline & Charcoal & $20 \mathrm{mM} \mathrm{NaNO}_{3}$ & & Fang et al. (2010) \\
\hline & Iron hydroxide & $0-3.2 \%$ salinity & & Randall and Weber (1986) \\
\hline & Soot & $20 \mathrm{mM} \mathrm{NaNO}_{3}$ & $\begin{array}{l}\text { Adsorption of TBT increases with } \\
\text { increasing pH from } 3 \text { to } 7 \text { and } \\
\text { then keeps constant at higher } \mathrm{pH}\end{array}$ & Fang et al. (2010) \\
\hline \multirow[t]{4}{*}{ DBT } & Montmorillonite, kaolinite & $3.2 \%$ saline water & \multirow{2}{*}{$\begin{array}{l}\text { Adsorption of DBT increases from } \\
\mathrm{pH} 4 \text { to } \mathrm{pH} 7 \text { and decreases at } \\
\text { higher } \mathrm{pH} \text {. }\end{array}$} & Hoch et al. (2003) \\
\hline & Estuarine sediment & Seawater & & Dai et al. (2003) \\
\hline & Iron hydroxide & $0-3.2 \%$ salinity & $\begin{array}{l}\text { DBT adsorption decreases from } \mathrm{pH} \\
\quad 6 \text { to } 8\end{array}$ & Randall and Weber (1986) \\
\hline & Charcoal & $20 \mathrm{mM} \mathrm{NaNO}_{3}$ & $\begin{array}{l}\text { No significant change from } \mathrm{pH} 4 \text { to } 7 \\
\text { and then decreases at higher } \mathrm{pH}\end{array}$ & Fang et al. (2012) \\
\hline \multirow[t]{3}{*}{ MBT } & Iron hydroxide & $0-3.2 \%$ salinity & \multirow{3}{*}{$\begin{array}{l}\text { MBT adsorption decreases from } \mathrm{pH} \\
6 \text { to } 8\end{array}$} & Randall and Weber (1986) \\
\hline & Charcoal & $20 \mathrm{mM} \mathrm{NaNO}_{3}$ & & Fang et al. (2012) \\
\hline & Estuarine sediment & Seawater & & Dai et al. (2003) \\
\hline
\end{tabular}


different from other adsorbents such as humic acid and clays, implying the different adsorption mechanisms of soot from other adsorbents (Fang et al. 2010). Despite that findings of the $\mathrm{pH}$ effect on the TBT adsorption were obtained based on different experimental conditions with diverse salinity (e.g., from 0 to 32), it seems that the effect of salinity on the TBT adsorption is insignificant in comparison to $\mathrm{pH}$ (Langston and Pope 2001; Bangkedphol et al. 2009; Randall and Weber 1986). A similar trend is also found for the DBT adsorption towards sediment and clays from $\mathrm{pH} 4$ to 8 and under various salinities reported by Dai et al. (2003) and Hoch et al. (2003), while Fang et al. (2012) found that the adsorption of DBT to charcoal remains constant from $\mathrm{pH} 4$ to 7. Unlike TBT and DBT, the adsorption of MBT to sediment, iron oxide, or charcoal decreases consistently from $\mathrm{pH}$ 6 to 8, showing an opposite adsorption tendency to that for TBT and DBT from pH 6 to 7 (Dai et al. 2003; Fang et al. 2012; Randall and Weber 1986).

\section{Environmental matrices}

Soils and sediments are complex and heterogenic matrices containing clays, sand (quartz), natural organic matters (NOMs), and BCs. To illustrate the contribution of different components to the total adsorption of BTs, a "back of envelop calculation" is useful. We take TBT as an example where TBT is adsorbed at $\mathrm{pH} 6$ and 8 by a sediment consisting of $95.4 \%$ sand (>90\% quartz), $2 \%$ clay (kaolinite), and $2.6 \% \mathrm{C}$ in NOM and BC with a BC to OM ratio of 0.25 (Burton et al. 2004; Hammes et al. 2007). A typical concentration range of TBT in water is from 0 to $500 \mathrm{ng} \mathrm{L}^{-1}$ (Antizar-ladislao 2008; Nielsen and Strand 2002; Weidenhaupt et al. 1997). The TBT distribution coefficients of the adsorbents were taken from the literature (Arnold et al. 1998; Fang et al. 2010; Weidenhaupt et al. 1997). The total adsorbed TBT by the sediment, $q_{\text {total }}$, is given by the Eq. 3:

$$
\begin{aligned}
q_{\text {total }}= & C_{\mathrm{w}} f_{\mathrm{k}} K_{\mathrm{k}}+C_{\mathrm{w}} f_{\mathrm{s}} K_{\mathrm{s}}+C_{\mathrm{w}} f_{\mathrm{OM}} K_{\mathrm{OM}} \\
& +f_{\mathrm{BC}} C_{\mathrm{w}} K_{\mathrm{BC}}
\end{aligned}
$$

where $f_{\mathrm{k}} f_{\mathrm{s}}, f_{\mathrm{NOM}}$, and $f_{\mathrm{BC}}$ represent the fractions of kaolinite, sand, $\mathrm{OM}$, and $\mathrm{BC}$, respectively. $K_{\mathrm{K}}, K_{\mathrm{s}}, K_{\mathrm{NOM}}$, and $\mathrm{K}_{\mathrm{BC}}$ represent the distribution coefficients of TBT with kaolinite, sand, $\mathrm{OM}$, and $\mathrm{BC}$, respectively. $C_{\mathrm{w}}$ represents the concentration of TBT in aqueous phase.

On the basis of this rough calculation, the results are given in Table 7. It is shown that NOM contributes the most to the total adsorption of TBT ranging from 55 to $85 \%$ among the four adsorbents in all cases except that of $31 \%$ in the low TBT concentration at $\mathrm{pH} 8 \mathrm{BC}$ is found to contribute the most (57\%) to the total TBT adsorption in a low TBT concentration at $\mathrm{pH} 8$ and shows the least contribution (10\%) at high TBT concentration and $\mathrm{pH} 6$, but is still considerably higher than clay (Table 7).
Table 7 Contribution of different natural adsorbents to the total tributyltin (TBT) adsorption

\begin{tabular}{llllll}
\hline \multirow{2}{*}{ TBT concentration } & $\mathrm{pH}$ & \multicolumn{4}{l}{ Contribution to the total adsorption of TBT (\%) } \\
\cline { 2 - 5 } & & Sand & Clay & NOM & BC \\
\hline $100 \mathrm{ng} \mathrm{L}^{-1}$ & 6 & $3 \%$ & $1 \%$ & $74 \%$ & $22 \%$ \\
& 8 & $10 \%$ & $2 \%$ & $31 \%$ & $57 \%$ \\
$100 \mu \mathrm{g} \mathrm{L}^{-1}$ & 6 & $4 \%$ & $1 \%$ & $85 \%$ & $10 \%$ \\
& 8 & $17 \%$ & $4 \%$ & $55 \%$ & $24 \%$ \\
\hline
\end{tabular}

These findings indicate that the contribution by the adsorbents highly depends on the TBT concentration and $\mathrm{pH}$.

\section{Competitive adsorption}

Competition for adsorption sites between the positively charged BTs and background ions such as $\mathrm{Ca}^{2+}$ and $\mathrm{Mg}^{2+}$ may seriously affect the adsorption of BTs to adsorbents, but very limited experimental evidence exists to date. Weidenhaupt et al. (1997) studied the adsorption of TBT to minerals at $\mathrm{pH} 4$ in the presence of different cations and showed that the adsorption of TBT significantly declined when the monovalent cations' electrolyte (e.g., $\mathrm{Na}^{+}$and $\mathrm{K}^{+}$) was replaced by bivalent cations (e.g., $\mathrm{Ba}^{2+}$, $\mathrm{Ca}^{2+}$, and $\left.\mathrm{Mg}^{2+}\right)$. The authors interpreted this decline due to the bivalent cations competing for exchangeable sites on the surface of minerals with cationic $\mathrm{TBT}^{+}$, the dominant species of TBT at pH 4 (Weidenhaupt et al. 1997). This is in good agreement with the finding by Hoch and Schwesig (2004) showing that the adsorption of TBT to sediment dramatically decreases in seawater compared to that in freshwater at the similar $\mathrm{pH}$ range. In addition, the influence of cations on $\mathrm{TBT}^{+}$adsorption to negatively charged sites differs depending on the cation radius. The larger hydrated cations (e.g., $\mathrm{Cs}^{+}$) can decrease TBT adsorption more than the smaller ones (e.g., $\mathrm{Na}^{+}$) (Weidenhaupt et al. 1997). It was shown that the competitive adsorption can also occur between BTs (Fang et al. 2012); the presence of DBT with comparable concentration can significantly decrease the adsorption of TBT to charcoal at $\mathrm{pH}<6$, whereas the adsorption of TBT is irrespective to the presence of DBT at $\mathrm{pH} 8$. However, it is suggested that the competitive effect of DBT is negligible in comparison to that of inorganic cations (e.g., $\mathrm{Na}^{+}, \mathrm{Ca}^{2+}$ ) in the environment, as the concentration of such cations are much higher than BTs.

\section{Comparison of BT adsorption}

Studies have shown that the adsorption behaviors of the three BTs are significantly different. Huang and Matzner (2004) studied the adsorption of the three BTs to soils in artificial rainwater at $\mathrm{pH}<5$, showing that the adsorption capacity of BTs to soils is in an order of MBT $>$ DBT $>$ TBT. A similar 
finding was also reported on the BT adsorption to sediment and charcoals (Dai et al. 2003; Fang et al. 2012). This can be due to the fact that MBT is more positively charged than DBT and TBT, and hence, MBT can be more strongly bonded via electrostatic forces at $\mathrm{pH}<7$ (Huang and Matzner 2004). However, Fang et al. (2012) reported an opposite trend showing that the adsorption of BTs to charcoal is in an order of TBT $>$ DBT $>$ MBT at $\mathrm{pH}$ 8. This can be due to that the predominant neutral TBT species at $\mathrm{pH} 8$ shows a higher hydrophobicity than the neutral DBT and MBT species, and consequently leading to stronger hydrophobic adsorption to charcoal (Fang et al. 2012).

\section{BT adsorption mechanisms}

The adsorption of TBT is mainly governed by the adsorption of $\mathrm{TBT}^{+}$to the negatively charged surfaces via electrostatic forces at $\mathrm{pH}<6.3$. Although the fraction of $\mathrm{TBT}^{+}$decreases with increasing $\mathrm{pH}$, the adsorption of TBT to adsorbents increases. This can be attributed to deprotonation of the functional groups enhancing the negative sites on the surfaces of adsorbents. It is considered to be a compromise of the fractions between $\mathrm{TBT}^{+}$and negative charge sites at the neutral pH range (Fang et al. 2011; Weidenhaupt et al. 1997). At $\mathrm{pH}>6.3$, the neutral TBTOH species dominates in water (Fig. 1), and hence, the hydrophobic adsorption of neutral TBTOH species to the hydrophobic surface of adsorbents is considered to be a prevailing mechanism for TBT adsorption (Arnold et al. 1998; Hoch et al. 2002).

MBT and DBT are mainly presented as a mixture of dicharged and monocharged species at $\mathrm{pH} 3$ to 6 (Fig. 1; Fang et al. 2012). Hence, the electrostatic bonding of the positively dicharged and monocharged MBT and DBT species by the negatively charged sites on adsorbents can take place at $\mathrm{pH}<6$. Nevertheless, in comparison to the monocharged BT species (e.g., $\mathrm{TBT}^{+}$), the dicharged BT species (i.e., $\mathrm{MBT}(\mathrm{OH})^{2+}$ and $\left.\mathrm{DBT}^{2+}\right)$ may exhibit stronger affinity to the negatively deprotonated functional groups on adsorbents. This is also observed in the competitive adsorption of DBT and TBT at $\mathrm{pH}<6$ reported by Fang et al. (2012). At $\mathrm{pH}>6$, the neutral MBT and DBT species (i.e., $\mathrm{MBT}(\mathrm{OH})_{3}$ and $\left.\mathrm{DBT}(\mathrm{OH})_{2}\right)$ are presented as dominant species in water (Fang et al. 2012), and hence, the adsorption of MBT and DBT to adsorbents is prevailing by hydrophobic adsorption at $\mathrm{pH}>6$.

Several models have been suggested to describe the BT adsorption by various adsorbents, including the simplest linear isotherm for the adsorption of BTs to clays, humic acid, and metal oxides (e.g., Huang and Matnzer 2004; Hoch et al. 2003; Weidenhaupt et al. 1997) and the nonlinear Langmuir and Freundlich models for BT adsorption to quartz and BCs (Bueno et al. 1998; Behra et al. 2003; Fang et al. 2010, 2012). In addition, a few semi-empirical models were developed to elucidate the mechanism of BT adsorption. Arnold et al.
(1998) modeled the humic acid to water partitioning of TBT by assuming that charged $\mathrm{TBT}^{+}$species adsorbs on four discrete bonding sites on humic acid. Hoch and Weerasooriya (2005) proposed a diffused double layer model (DLM) that treats the surface of montmorillonite as a nonpenetrable solid with three types of sites (i.e., $\mathrm{pH}$-independently permanent charge sites, $\mathrm{pH}$-dependent selective and nonselective charge sites). The model reveals that the adsorption of TBT to selective charged sites on the adsorbent remains constant and higher than to other two types of sites. Furthermore, a new $\mathrm{pH}$-dependent dual Langmuir ( $\mathrm{pH}-\mathrm{DL}$ ) model was proposed by Fang et al. (2012) giving a quantitative depiction of adsorption of the bicharged BT species (i.e., $\mathrm{DBT}^{2+}$ and $\left.\operatorname{MBT}(\mathrm{OH})^{2+}\right)$, the monocharged BT species (i.e., $\mathrm{TBT}^{+}$, $\mathrm{DBT}(\mathrm{OH})^{+}$, and $\left.\mathrm{MBT}(\mathrm{OH})_{2}^{+}\right)$, and the neutral BT species (i.e., TBTOH, $\mathrm{DBT}(\mathrm{OH})_{2}$, and $\left.\operatorname{MBT}(\mathrm{OH})_{3}\right)$ to BCs. It was shown that the electrostatic bonding of the dicharged BT species to a wheat charcoal is about 5 to 12 times stronger than that for the monocharged BT species, while the hydrophobic adsorption of the neutral BT species is much weaker than that of the monocharged BT species (Fang et al. 2012).

\section{Desorption of BTs}

Desorption behavior of BTs from environmental matrices is another important process, which can significantly alter the bioavailability and toxicity of BTs in the environment. In contrast to extensive studies on adsorption of BTs, only a few studies have been done in desorption of BTs (Berg et al. 2001; Burton et al. 2004; Gui et al. 2016; Huang and Matzner 2004; Ruiz et al. 2008; Watanabe et al. 1997). It suggests that desorption of BTs follows a biphasic kinetics with an initial rapid desorption and a later slower desorption (Ma et al. 2000). Desorption rate of BTs from sediment is highly dependent on the property of BTs with an order of TBT $>$ DBT > MBT at both pH 8 and 4 (Huang and Matzner 2004; Watanabe et al. 1997). Moreover, BT desorption from environmental matrices highly depends on environmental factors (e.g., $\mathrm{pH}$ and salinity) and property of matrices, which is specified as below.

\section{Effect of salinity}

There is limited knowledge on the effect of salinity on desorption of BTs to date. Burton et al. (2004) found no significant difference between the desorption rate of TBT from a marine sediment at the salinity of 5 and that at the salinity of 35 at the same $\mathrm{pH}$ conditions. Their findings also reveal that the effect of salinity on TBT desorption is not affected by $\mathrm{pH}$, showing that both positively charged TBT species and neutral TBT species show the similar desorption rate. Conversely, Sakultantimetha et al. (2011) reported that the desorption rate 
of TBT increases from 13 to $33 \%$ with the increase of salinity from 0 to 20 at $\mathrm{pH} 7.5$, however decreases with further increasing salinity from 20 to 30 . The increase of TBT desorption rate from salinity of 0 to 20 can be due to the competitive adsorption of cationic ions (e.g., $\mathrm{Ca}$ and $\mathrm{Mg}$ ) to sediment, consequently stimulating the desorption of the positively charged TBT species $(\sim 10 \%)$ from sediment at $\mathrm{pH}$ 7.3. The decline of TBT desorption rate from salinity of 20 to 30 can be due to the salting out effect that increases the binding affinity of hydrophobic adsorption of the neutral TBT species. Nevertheless, contradictory findings have been observed between the studies by Burton et al. (2004) and Sakultantimetha et al. (2011), which can be due to different experimental methods used in the two studies; Burton et al. (2004) performed the adsorption and desorption experiments under the same salinity. However, Sakultantimetha et al. (2011) examined the desorption rate of TBT under different salinities after adsorption of TBT on sediment, which is more relevant for assessing the fate of TBT in TBT-adsorbed sediment particles transporting from freshwater to estuarine and marine system.

\section{Effect of pH}

Several groups investigated the effect of $\mathrm{pH}$ on the desorption of TBT and DBT from different adsorbents such as marine sediment, kaolinite, and montmorillonite, and a similar desorption behavior was observed showing that desorption of TBT and DBT can occur at a pH range from 4 to 8 (Burton et al. 2004; Hoch et al. 2002, 2003). Their results also show that desorption trend of BTs as a function of $\mathrm{pH}$ is in opposite to that of BT adsorption; the maximum desorption rate of BTs takes place at $\mathrm{pH} 8$, and the minimum desorption rate occurs at $\mathrm{pH}$ ranging from 6 to 7 . The higher desorption of BTs at $\mathrm{pH} 8$ may be due to the fact that the hydrophobic interaction force of the neutral BT species with environmental matrices at $\mathrm{pH} 8$ is weaker than the electrostatic force between the positively charged $\mathrm{BT}$ species and matrices at $\mathrm{pH}<6$.

\section{Effect of environmental matrices}

Desorption of BTs from environmental matrices is different depending on the property of matrices. The content of organic carbon is regarded as an important factor that affects desorption of BTs. Burton et al. (2006) observed a hysteric desorption of TBT from sediment at $\mathrm{pH} 8$, which is due to the slow diffusion of TBT molecules from the internal sites of sediment with organic carbon content ranging from 0.2 to $4.8 \%$. Huang and Matzner (2004) also reported a similar finding showing that TBT and DBT desorption rate remarkably declines from 33 to less $1 \%$ with the increase of organic carbon content from 1.6 to $44.3 \%$ even at $\mathrm{pH}<5.5$ where TBT and DBT are predominant as positively charged species. In addition, study shows that desorption rate of TBT from organic carbon-rich sediment becomes more difficult by increasing the aging time from $24 \mathrm{~h}$ to 84 days (Ma et al. 2000). However, there is no significant difference for TBT and DBT desorption from kaolinite, illite, and montmorillonite in seawater at $\mathrm{pH} 8$ where both of BTs are predominant as neutral species (Hoch et al. 2002, 2003).

\section{Toxicity and bioaccumulation of BTs}

Since the first evidence of TBT causing imposex in gastropod mollusks was reported in the 1970s, a number of studies have been devoted to assess the toxicity of BTs to different organisms (Matthiessen and Gibbs 1998; Giraud-Billoud et al. 2013; Graceli et al. 2013; Lopes-dos-Santos et al. 2014). The susceptibility of individuals to toxic exposure of BTs may differ due to their different genotypes, rate of metabolism, ontogenetic development, and environmental conditions (Fent 1996; Fernandez et al. 2005; Sahoo and Oikari 2016). As a consequence, the effect concentration (EC) of BTs to different organisms falls in a wide range. Determination of BT toxicity has been conducted in acute and chronic tests. For acute toxicity, the EC mainly relates to the mortality (immobilization of organism) and the growth inhibition during a short period of exposure, while the chronic effects of BTs are essentially of importance at low concentration and longterm exposure. In addition, studies demonstrated that bioaccumulation of BTs in organisms is an important parameter to predict BT toxicity and threats to higher trophic levels in the food chain. It is found that the bioaccumulation of BTs can be affected by many extrinsic factors such as the concentration of organic carbon, the presence of adsorbents, $\mathrm{pH}$, water hardness, and salinity (Bartlett et al. 2004).

This section briefly reviews the acute and chronic toxicity of BTs to different species of organism and bioaccumulation of BTs in aquatic organisms. More importantly, influence of environmental factors and environmental matrices on toxicity and bioaccumulation of BTs is extensively addressed.

\section{Toxicity of BTs}

Among the three BTs, TBT is considered as the most toxic to aquatic organisms, while DBT is less toxic and MBT is the least toxic (Fent 1996; Li and Li 2015). Many studies have been undertaken on the toxicity of BTs to different life stages of organisms. The selected data are listed in Table 8.

The early stage of embryos and larvae is generally used as a model for assessing the water quality, since they are more susceptible to toxicant than in their adult stages (Sahoo and Oikari 2016). For instance, Lau et al. (2007) performed an acute toxicity test of TBT to different stages of polychaete, Hydroides elegans, i.e., eggs, two cells, trochophores, juveniles, and adults, in static seawater. The results showed that the $48 \mathrm{~h} \mathrm{LC}_{50}$ value (the concentration causing $50 \%$ of lethality in all test populations) for these stages from eggs to adults was $0.2,1.0,2.4,2.9$, and $4.4 \mu \mathrm{g}$ (TBT) 
Table 8 Selected studies on the acute toxicity results of butyltins (BTs) to aquatic organisms

\begin{tabular}{|c|c|c|c|c|c|}
\hline Butyltin & Organism & Media & Time & $\mathrm{LC}_{50}\left(\mu \mathrm{g} \mathrm{Sn} \mathrm{L}^{-1}\right)$ & Reference \\
\hline \multirow[t]{10}{*}{ TBT } & Nauplius neonate (Eurytemora affinis) & Artificial seawater & $48-72 \mathrm{~h}$ & $0.6-2.2$ & Hall et al. (1988) \\
\hline & Crustacean neonate (D. magna) & Artificial freshwater & $96 \mathrm{~h}$ & $3.3-5.5$ & Meador (1986) \\
\hline & Oyster (C. virginica), embryos & River water & $48 \mathrm{~h}$ & 1.3 & Roberts (1987) \\
\hline & M. mercenaria, embryos & River water & $48 \mathrm{~h}$ & 1.1 & \\
\hline & Crustacean juvenile (Mysid shrimp) & Seawater & $96 \mathrm{~h}$ & 0.3 & Valkirs et al. (1987) \\
\hline & Seabream larvae (Sparus aurata L.) & Seawater & $24 \mathrm{~h}$ & 38.6 & Dimitriou et al. (2003) \\
\hline & Echinoidea larvae (P. lividus) & Artificial seawater (salinity $3.4 \%$; pH 8) & $24 \mathrm{~h}$ & 0.3 & Bellas et al. (2005) \\
\hline & Crustacea larval (P. serratus) & & $24 \mathrm{~h}$ & 17.5 & \\
\hline & Tilapia & Artificial seawater (salinity $1.5 \%$ ) & $96 \mathrm{~h}$ & 3.8 & Lei et al. (1998) \\
\hline & Crustacean neonate (D. magna) & Artificial freshwater at $\mathrm{pH}$ 6-8 & $48 \mathrm{~h}$ & $2.7-3.4$ & Fang et al. (2011) \\
\hline \multirow[t]{2}{*}{ DBT } & Crustacean neonate (D. magna) & M7 test media & $24 \mathrm{~h}$ & 900 & Vighi and Calamari (1985) \\
\hline & Crustacean neonate (D. magna) & Artificial freshwater at $\mathrm{pH} 6-8$ & $48 \mathrm{~h}$ & $330-484$ & Fang et al. (2011) \\
\hline MBT & Crustacean neonate (D. magna) & M7 test media & $24 \mathrm{~h}$ & 49,000 & Vighi and Calamari (1985) \\
\hline
\end{tabular}

$\mathrm{L}^{-1}$. Another analogous finding was also reported for seabream (Sparus aurata) eggs and its larvae, which gave lower $24 \mathrm{~h} \mathrm{LC}_{50}$ of $28.3 \mu \mathrm{g} \mathrm{L}^{-1}$ for the eggs than that of $38.6 \mu \mathrm{g} \mathrm{L}^{-1}$ for larvae (Dimitriou et al. 2003). This is ascribed to the increased sensitivity of the earlier stage due to the rapidity of development and abundant availability (Antizar-Ladislao 2008; Dimitriou et al. 2003). In contrast, the later life stages of some organisms are found to be more sensitive to TBT than the earlier life stages. Novelli et al. (2002) observed that the $\mathrm{EC}_{50}$ value of TBT for the egg stage of Mediterranean sea urchins, Paracentrotus livivdus, was $5.8 \mu \mathrm{g} \mathrm{L}^{-1}$ which was about two times higher than that of the embryonic stage $\left(2.5 \mu \mathrm{g} \mathrm{L}^{-1}\right)$ and may be due to the different targets (DNA and protein synthesis inhibition) for this species. This is also in accordance with the findings of toxicity of TBT in the adult mollusk, Mytilus edulis, by Haggera et al. (2005).

For the acute toxicity of DBT and MBT, very little information can be obtained in the literature. Vighi and Calamari (1985) observed a $24 \mathrm{~h} \mathrm{LC}_{50}$ value of $900 \mu \mathrm{g} \mathrm{L}^{-1}$ for DBT and $49,000 \mu \mathrm{g} \mathrm{L}^{-1}$ for MBT, respectively, for the crustacean, Daphnia magna. Fang et al. (2011) has also found a $48 \mathrm{~h} \mathrm{EC}_{50}$ value of 330 to $484 \mu \mathrm{g} \mathrm{L}^{-1}$ for DBT using the same test organism and experimental condition, which shows significantly higher $\mathrm{LC}_{50}$ value than for TBT $\left(3.2 \mu \mathrm{g} \mathrm{L}^{-1}\right.$; Fang et al. 2011). This may imply that the acute toxicity of TBT is significantly higher than that of DBT and MBT.

On the other hand, chronic toxicity of BTs can also highly depend on life stages of organisms (Leung et al. 2004; Li et al. 2014). For example, Ruppert et al. (2016) reported that the 18-day $\mathrm{EC}_{50}$ (the concentration causing 50\% of inhibition in all test populations) value ( $535 \mathrm{ng} \mathrm{Sn} \mathrm{L}^{-1}$ ) for adult snails is about 10 times higher than that for juvenile snails (50.8 $\mathrm{ng} \mathrm{Sn} \mathrm{L}^{-1}$ ). Similarly, Lau et al. (2007) reported that the $\mathrm{EC}_{50}$ value for the development of $H$. elegans (polychaete) from eggs to juveniles increases from 0.01 to $0.1 \mu \mathrm{g} \mathrm{L}^{-1}$ for an exposure period of 17 days.

\section{Bioaccumulation of BTs}

Because bioaccumulation in organisms can be via adsorption from water and sediment, or via food chain, this section hereby discusses the bioaccumulation of BTs in the context of phytoplankton and zooplankton. Bioaccumulation of BTs from seawater by phytoplankton is considered to take place at a short timescale (minutes to hours). Coelho et al. (2002) studied the bioaccumulation of TBT by the microalgae, Isochrysis galbana, in seawater (salinity of 30). The results show that the bioaccumulation of TBT is rather fast and reaches steady state after exposure for $1 \mathrm{~h}$, with a bioconcentration factor (BCF) of around $7000 \mathrm{~L} \mathrm{~kg}^{-1}$. The rapid bioaccumulation of TBT by the microalgae can be attributed to the large surface area of microalgae. Besides, a BCF of 1000 to $10,000 \mathrm{~L} \mathrm{~kg}^{-1}$ for TBT to the microalgaes (i.e., D. salina, D. vivides, and I. galbana) exposed to 1 to $100 \mu \mathrm{g} \mathrm{L}^{-1}$ of TBT has been reported in the literature (Guolan and Yong 1995; StLouis et al. 1997; Coelho et al. 2002). St-Louis et al. (1997) studied the mechanism of TBT bioaccumulation by the marine microalga Pavlova lutheri. They demonstrated that bioaccumulation of TBT by algae could involve two independent processes: surface bioaccumulation of cells and intracellular uptake. The surface binding is the major process which also explains the reason of rapid bioaccumulation of TBT by algae.

On the other hand, bioaccumulation of BTs from water/ sediment by zooplankton is found to be considerably slower than their bioaccumulation by phytoplankton (Seligman et al. 1996; Strand and Asmund 2003). For example, TBT was gradually taken up from water and sediment by the crustacean Hyalella azteca over the first $96 \mathrm{~h}$ and then reaches steady state after 25-day exposure, with a BCF around 1000 (Bartlett et al. 2004). The slow bioaccumulation rate is consistent with the findings of the bioaccumulation rate of TBT in fish larvae, Thymallus (Fent and Looser 1995), and fish muscles (e.g., Megalaspis 
cordyla) with a BCF value of 590 to $3263 \mathrm{~L} \mathrm{~kg}^{-1}$ (Shue et al. 2014). In addition, a very low BCF has been reported by Stronkhorst et al. (1999) who reported that the BCF of TBT for the heart urchin, Echinocardium cordatum, is only around 200. Bioaccumulation of TBT by zooplanktons is suggested to occur via the food chain, showing a relatively slow bioaccumulation rate (Coelho et al. 2002).

\section{Effect of environmental factors}

Environmental factors and matrices can alter the adsorption and desorption of BTs (Filipkowska et al. 2014; Furdek et al. 2016), consequently affecting the toxicity and bioaccumulation of BTs to organisms reported in many studies. In the following, the effect of different environmental factors and matrices on the toxicity and bioaccumulation of BTs is discussed.

\section{$p H$}

Depending on the $\mathrm{pH}$ of water, BT species can pose different physicochemical properties to organisms, such as lipophilicity/ hydrophobicity. White and Tobin (2004) investigated the toxicity of TBT to yeast, Candida maltosa, at pH 5.5 and 7.5, and observed a slight increase in toxicity at higher $\mathrm{pH}$. However, the membrane was found to be more damaged at $\mathrm{pH} 5.5$ than that at $\mathrm{pH}$ 7.5. Fent and Looser (1995) reported that TBT causes a three times higher mortality for D. magna at $\mathrm{pH} 8$ than that at pH 6 using a single TBT concentration of $4.8 \mu \mathrm{g} \mathrm{L}{ }^{-1}$. In contrast, Fang et al. (2011) reported that the $48-\mathrm{h} \mathrm{EC}_{50}$ value of TBT and DBT to D. magna is 2.7 and $190 \mu \mathrm{g} \mathrm{L}^{-1}$ at $\mathrm{pH}$ 6, respectively, and 3.2 and $331 \mu \mathrm{g} \mathrm{L}-1$ for TBT and DBT at $\mathrm{pH} 8$. The results showed the consistently higher toxicity for the two BTs at pH 6, especially for DBT (Fang et al. 2011), and are consistent with the finding of the membrane-damaging effects of TBT to C. maltosa. Phosphate buffer can strongly bind with the cationic $\mathrm{TBT}^{+}$species and has been used in Fent and Looser (1995). This may lead to the discrepancy between the two studies on the TBT toxicity to D. magna.

Several studies have also been involved in the effect of $\mathrm{pH}$ on the bioaccumulation of BTs by organisms. Fang et al. (2011) observed no significant difference between the BT bioaccumulations at $\mathrm{pH} 8$ and $\mathrm{pH} 6$ for both TBT and DBT. This is in accordance with the finding by Ciucani et al. (2004) showing no significant effect of $\mathrm{pH}$ on the bioaccumulation of TBT in willow trees.

\section{Salinity and hardness}

The effect of salinity and hardness on the toxicity of BTs has been reported. Hall et al. (2000) reported that the acute 10th percentiles of TBT for 43 saltwater species and 23 freshwater species are 320 and $103 \mathrm{ng} \mathrm{L}^{-1}$, showing significantly lower toxicity to those organisms in saltwater than in freshwater. Kwok and Leung
(2005) stated that the acute toxicity of TBT to the crustacean, Trissolcus japonicas, is much higher at a salinity of 15 than that at 45 . Fang and coworkers compared the acute toxicity of TBT and DBT to D. magna in media of different hardness and showed that the $\mathrm{EC}_{50}$ values for TBT and DBT were enhanced with increasing the hardness from 0.6 to $2.5 \mathrm{mM}$ (Fang et al. 2011). These findings reflect that the attenuated toxicity at a higher ionic strength (i.e., higher hardness or salinity) can be due to the competition of the background cations with BTs to biotic ligands on the organism. Nevertheless, the acute toxicity of TBT to the copepod, Acartia tonsa, slightly increased with an increase of salinity from 18 to 28 as reported by Kusk and Petersen (1997).

Although water salinity is also considered to be an important parameter for the bioaccumulation of BTs in organisms, very little work has been done on the effect of hardness or salinity on the bioaccumulation of BTs. It is noted that the BCF values of TBT in freshwater fish is also identical with those observed in fish in seawater at $\mathrm{pH} 8$, showing insignificant effect of salinity on the bioaccumulation of TBT (Fent 1996).

\section{Effect of environmental matrices}

Environmental matrices such as humic acids and BCs can strongly associate with BTs, consequently affecting the BT bioavailability in the environment (Burton et al. 2004; Fang et al. 2011, 2012; Weidenhaupt et al. 1997). Bao et al. (1997) studied the acute toxicity of TBT to D. magna by the addition of different types of humic acids, and their results show that the 24 or $48 \mathrm{~h}$ $\mathrm{EC}_{50}$ value for TBT remarkably increases after the addition of $40 \mathrm{mg} \mathrm{L}^{-1}$ of humic acid, which indicates that the toxicity of organisms significantly decreases. The decrease of TBT bioaccumulation in the presence of humic acid was also observed by Fent and Looser (1995), which is in line with the findings by Fang et al. (2011) showing that the presence of nano-size charcoal can notably decrease the acute toxicity of TBT and DBT to D. magna. Conversely, Bartlett et al. (2004) found that the TBT bioaccumulation in H. azteca is much higher in the presence of sediment during exposure. Analogously, the presence of humic acid in the sediment-associated TBT was found to significantly increase the toxicity of TBT on the Rhepoxynius abronius and Eohaustorius washingtonianus (Meador et al. 1997).

\section{Conclusion}

BTs, namely TBT, DBT, and MBT, are the most important organometallic compounds in the industry and agriculture. The release of BTs into ecosystems can cause severely adverse effect to the environment and organisms. Study on the fate and toxicity of BTs in the environment has been intensively engaged during the past decades. This work reviews the recent progress of BT studies in relation with their physicochemical properties and environmental levels, adsorption and 
desorption of BTs to different environmental matrices, and their bioaccumulation and toxicity to organisms. Lab-scale studies have demonstrated that environmental factors (e.g., $\mathrm{pH}$, temperature, and salinity) and environmental matrices (e.g., minerals and BCs) can significantly influence the adsorption and desorption of BTs to matrices, and consequently altering their bioaccumulation and toxicity to organisms. These evidences can be useful for properly assessing the bioavailability and toxicity of BTs in the environment. However, further field study on the overall influence of these environmental factors is essentially demanded. Meanwhile, development of relevant remediation technology for BT-contaminant sediments particularly in marine systems is also highly required.

Acknowledgments The current work was financially supported by the National Natural Science Foundation of China (Grant No. 21407131) and the Fundamental Research Funds for the Central University, China University of Geosciences (Wuhan) (CUG150602).

\section{References}

Antizar-Ladislao B (2008) Environmental levels, toxicity and human exposure to tributytlin (TBT) to contaminated marine environment. A review. Environ Int 34:292-308

Arnold CG, Ciani A, Muller SR, Amirbahman A, Schwarzenbach RP (1998) Association of triorganotin compounds with dissolved humic acids. Environ Sci Technol 32:2976-2983

Arnold CG, Weidenhaupt A, David MM, Muller SR, Haderlein SB, Schwarzenbach RP (1997) Aqueous speciation and 1-octanolwater partitioning of tributyl and triphenyltin: effect of $\mathrm{pH}$ and ion composition. Environ Sci Technol 31:2596-2602

Bangkedphol S, Keenan HE, Davidson C, Sakultantimetha A, Songsasen A (2009) The partition behavior of tributyltin and prediction of environmental fate, persistence and toxicity in aquatic environments. Chemosphere 77:1326-1332

Bao ML, Dai SG, Pantani F (1997) Effect of dissolved humic material on the toxicity of tributyltin chloride and triphenyltin chloride to Daphnia magna. B Environ Contam Toxicol 59:671-676

Bartlett A, Borgmann U, Dixon DG, Batchelor SP, Maguire RJ (2004) Accumulation of tributyltin in Hyalella azteca as an indicator of chronic toxicity: survival, growth, reproduction. Environ Toxicol Chem 23:2878-2888

Batista RM, Castro IB, Fillmann G (2016) Imposex and butyltin contamination still evident in Chile after TBT global ban. Sci Total Environ 566-567:446-453

Behra P, Lecarme-Thqobald M, Bueno MCDAT, Ehrhardt JJ (2003) Sorption of tributyltin onto a natural quartz sand. J Colloid Interf Sci 263:4-12

Bellas J, Beiras R, Marino-Balsa JC, Fernandez N (2005) Toxicity of organic compounds to marine invertebrate embryos and larvae: a comparison between the sea urchin embryogenesis bioassay and alternative test species. Ecotoxicology 14:337-353

Berg M, Arnold CG, Muller SR, Muhlemann J, Schwarzenbach RP (2001) Sorption and desorption behavior of organotin compounds in sediment-pore water systems. Environ Sci Technol 35:3151-3157

Brandli RC, Breedveld GD, Cornelissen G (2009) Tributyltin sorption to marine sedimentary black carbon and to amended activated carbon. Environ Toxicol Chem 28:503-508
Bueno M, Astruc A, Astruc M, Behra P (1998) Dynamic sorptive behavior of tributyltin on quartz sand at low concentration levels: effect of $\mathrm{pH}$, flow rate, and monovalent cations. Environ Sci Technol 32: 3919-3925

Burton ED, Phillips IR, Hawker DW (2004) Sorption and desorption behavior of tributyltin with natural sediments. Environ Sci Technol 38:6694-6700

Burton ED, Phillips IR, Hawker DW (2006) Tributyltin partitioning in sediments: effect of aging. Chemosphere 63:73-81

Castro IB, Perina FC, Fillmann G (2012) Organotin contamination in South American coastal areas. Environ Monit Assess 184:1781-1799

Choi M, Choi HG, Moon HB, Kim GY (2009) Spatial and temporal distribution of tributyltin (TBT) in seawater, sediments and bivalves from coastal areas of Korea during 2001 and 2005. Environ Monit Assess 151:301-310

Choi M, Moon HB, Yu J, Cho H, Choi HG (2013) Temporal trends (2004-2009) of imposex in rock shells Thais Clavigera collected along the Korean coast associated with tributyltin regulation in 2003 and 2008. Arch Environ Con Tox 64:448-455

Ciucani G, Mosbaek H, Trapp S (2004) Uptake of tributyltin into willow trees. Environ Sci Pollut Res 11:267-272

Coelho MR, Bebianno MJ, Langston WJ (2002) Routes of TBT uptake in the clam Ruditapes decussate. Food as vector of TBT uptake. Mar Environ Res 54:193-207

Dai SG, Sun HW, Wang YQ, Chen WP, Li N (2003) Sorption behavior of butyltin compounds in estuarine environments of the Haihe river, China. ACS Symp Ser 835:370-387

Del Brio F, Commendatore M, Castro IB, Gomes Costa P, Fillmann G, Bigatti G (2016) Distribution and bioaccumulation of butyltins in the edible gastropod Odontocymbiola magellanica. Mar Biol Res 12:608-620

Dimitriou P, Castritsi-Catharios J, Miliou H (2003) Acute toxicity effects of tributyltin chloride and triphenyltin chloride on gilthead swabream, Sparus autata L., embryos. Ecotoxic Environ Safe 54:30-35

Eng G, Bathersfield O, May L (1986) Mossbauer studies of the speciation of tributyltin compounds in seawater and sediment samples. Water, Air, \&amp Soil Pollution 27:191-197

Fang LP, Borggaard OK, Marcussen H, Holm PE, Hansen HCB (2010) The $\mathrm{pH}$-dependent adsorption of tributyltin to charcoals and soot. Environ Pollut 158:3642-3649

Fang LP, Borggaard OK, Holm PE, Hansen HCB, Cedergreen N (2011) Toxicity and uptake of TRI- and dibutyltin in Daphnia magna in the absence and presence of nano-charcoal. Environ Toxicol Chem 30: 2553-2561

Fang LP, Borggaard OK, Christensen JH, Holm PE, Hansen HCB (2012) Adsorption of mono-, di-, and tributyltin by charcoal: $\mathrm{pH}$ effects and modeling. Chemosphere 89:863-868

Fent K (1996) Ecotoxicology of organotin compounds. Crit Rev Toxicol 26:3-117

Fent K, Looser PW (1995) Bioaccumulation and bioavailability of tributyltin chloride: influence of $\mathrm{pH}$ and humic acids. Water Res 29:1631-1637

Fernandez MA, Wagener ADR, Limaverde AM, Scofield AL, Pinheiro FM, Rodrigues E (2005) Imposex and surface sediment speciation: a combined approach to evaluate organotin contamination in Guanabara Bay, Rio de Janeiro, Brazil. Mar Environ Res 59:435-452

Filipkowska A, Kowalewska G, Pavoni B (2014) Organotin compounds in surface sediments of the Southern Baltic coastal zone: a study on the main factors for their accumulation and degradation. Environ Sci Pollut R 21:2077-2087

Frouin H, Lebeuf M, Saint-Louis R, Hammill M, Pelletier M, Fournier M (2008) Toxic effects of tributyltin and its metabolites on harbour seal (Phoca vitulina) immune cells in vitro. Aquat Toxicol 90:243-251

Furdek M, Mikac N, Bueno M, Tessier E, Cavalheiro J, Monperrus M (2016) Organotin persistence in contaminated marine sediments and porewaters: in situ degradation study using species-specific stable isotopic tracers. J Hazard Mater 307:263-273 
Gao JM, Zhang K, Chen YP, Guo JS, Wei YM, Jiang WC, Zhou B, Qiu H (2015) Occurrence of organotin compounds in river sediments under the dynamic water level conditions in the Three Gorges Reservoir Area, China. Environ Sci Pollut R 22:8375-8385

Giraud-Billoud M, Vega IA, Wuilloud RG, Clement ME, Castro-Vazquez A (2013) Imposex and novel mechanisms of reproductive failure induced by tributyltin (TBT) in the freshwater snail Pomacea canaliculata. Environ Toxicol Chem 32:2365-2371

Gui WJ, Tian CX, Sun QQ, Li SY, Zhang W, Tang J, Zhu GN (2016) Simultaneous determination of organotin pesticides by HPLC-ICPMS and their sorption, desorption, and transformation in freshwater sediments. Water Res 95:185-194

Gumy C, Chandsawangbhuwana C, Dzyakanchuk AA, Kratschmar DV, Baker ME, Odermatt A (2008) Dibutyltin disrupts glucocorticoid receptor function and impairs glucocorticoid-induced suppression of cytokine production. PLoS One 3:e3545

Guolan H, Yong W (1995) Effects of tributyltin chloride on marine bivlve mussels. Water Res 29:1877-1884

Graceli JB, Sena GC, Lopes PFI, Zamprogno GC, da Costa MB, Godoi AFL, dos Santos DM, de Marchi MRR, dos Santos Fernandez MA (2013) Organotins: a review of their reproductive toxicity, biochemistry, and environmental fate. Reprod Toxicol 36:40-52

Haggera JA, Depledge MH, Galloway TS (2005) Toxicity of tributyltin in the mollusk Mytilus edulis. Mar Pollut Bull 51:811-816

Hammes K, Schmidt MWI, Smernik RJ, Currie LA, Ball WP, Nguyen $\mathrm{TH}$ et al (2007) Comparison of quantification methods to measure fire-derived (black/elemental) carbon in soils and sediments using reference materials from soil, water, sediment and the atmosphere. Glob Biogeochem Cycles 21:GB3016

Hall LW, Bushong SJ, Hall WS, Johnson WE (1988) Acute and chronic effects of tributyltin on a Chesapeake Bay copepod. Environ Toxicol Chem 7:41-46

Hall LW, Scott MC, Killen WD, Unger MA (2000) A probabilistic ecological risk assessment of tributyltin in surface waters of the Chesapeake Bay watershed. Human Ecolog Risk Assess 141-179

Harino H, Fukushima M, Yamamoto Y, Kawai S, Miyazaki N (1998) Organotin compounds in water, sediment, and biological samples from the port of Osaka, Japan. Arch Environ Con Tox 35:558-564

Harris JRW, Cleary JJ (1987) Particle-environ Pollutpartioning and organotin dispersal in an estuary. Proc Confer Ocean'87 Organotin Symp 4:1370-1374

Hermosin MC, Martin P, Cornejo J (1993) Adsorption mechanisms of monobutyltin in clay minerals. Environ Sci Technol 27:2606-2611

Ho KKY, Leung KMY (2014) Spatio-temporal comparisons of imposex status and tissue organotin concentration in the whelk Reishia clavigera collected along the coasts of Dapeng Bay and Daya Bay, Shenzhen, China. Mar Pollut Bull 85:254-260

Hoch M (2001) Organotin compounds in the environment — an overview. Appl Geochem 16:719-743

Hoch M, Alonso-Azcarate J, Lischick M (2002) Adsorption behavior of toxic tributyltin to clay-rich sediments under various environmental conditions. Environ Toxicol Chem 21:1390-1397

Hoch M, Alonso-Azcarate J, Lischick M (2003) Assessment of adsorption behavior of dibutyltin (DBT) to clay-rich sediments in comparison to the highly toxic tributyltin (TBT). Environ Pollut 123:217-227

Hoch M, Weerasooriya R (2005) New model calculations of $\mathrm{pH}-$ depending tributyltin adsorption onto montmorillonite surface and montmorillonite-rich sediment. Environ Sci Technol 39:844-849

Hoch M (2004) Assessment of salinity variations in TBT adsorption onto kaolinite and montmorillonite at different $\mathrm{pH}$ levels. Water Air Soil Pollut 152:349-362

Hoch M, Schwesig D (2004) Parameters controlling the partitioning of tributyltin (TBT) in aquatic systems. Appl Geochem 19:323-334

Huang JH, Matzner E (2004) Adsorption and desorption of organotin compounds in organic and mineral soils. Euro J Soil Sci 55:693-698
Hunziker RW, Escher BI, Schwarzenbach RP (2001) pH dependence of the partitioning of triphenyltin and tributyltin between phosphatidylcholine liposomes and water. Environ Sci Technol 35:3899-3904

Hynes MJ, Odowd M (1985) Metal toxicity — complexing of alkyltin species with low-Mr ligands in aqueous-solution. Biochem Soc Trans 13:490-491

IMO (2005) Antifouling systems. International convention on the control of harmful anti-fouling systems on ships. International Maritime Organization, London

Inaba K, Shiraishi H, Soma Y (1995) Effects of salinity, pH and temperature on aqueous solubility of four organotin compounds. Water Res 29:1415-1417

Jacobsen JA, Asmund G (2000) TBT in marine sediments and blue mussels (Mytilus edulis) from central-west Greenland. Sci Total Environ 245:131-136

Kusk KO, Petersen S (1997) Acute and chronic toxicity of tributyltin and linear alkylbenzene sulfonate to the marine copepod Acartia tonsa. Environ Toxicol Chem 16:1629-1633

Kwok KWH, Leung KMY (2005) Toxicity of antifouling biocides ot the intertidal harpacticiod copepod Tigriopus japonicas (Crustacean, Copepoda): effect of temperature and salinity. Mar Pollut Bull 51: $830-837$

Laitano MV, Castro IB, Costa PG, Fillmann G, Cledon M (2015) Butyltin and PAH contamination of mar del Plata port (Argentina) sediments and their influence on adjacent coastal regions. B Environ Contam Tox 95:513-520

Landmeyer JE, Tanner TL, Watt BE (2004) Biotransformation of tributyltin to tin in freshwater river-bed sediments contaminated by an organotin release. Environ Sci Technol 38:4106-4112

Langston WJ, Pope ND (2001) Determinants of TBT adsorption and desorption in estuarine sediments. Mar Pollut Bull 31:32-43

Lau MC, Chan KM, Leung KMY, Luan Yang MS, Qiu JW (2007) Acute and chronic toxicities of tribuytlin to various life stages of the marine polychaete Hydroides elegans. Chemosphere 69:135-144

Laughlin RB, Guard HE, Coleman WM (1986) Tributyltin in seawaterspeciation and octanol water partition-coefficient. Environ Sci Technol 20:201-204

Lei H, Huang G, Dai S (1998) Toxicity and accumulation of tributyltin chloride on tilapia. Appl Organomet Chem 12:109-119

Leung KMY, Morley NJ, Grist EPM, Morritt D, Crane M (2004) Chronic toxicity of tributyltin on development and reproduction of the hermaphroditic snail Physa fontinalis: influence of population density. Mar Environ Res 58:157-162

Li ZH, Li P, Shi ZC (2014) Molecular responses in digestive tract of juvenile common carp after chronic exposure to sublethal tributyltin. Ecotox Environ Safe 109:10-14

Li ZH, Li P (2015) Evaluation of tributyltin toxicity in Chinese rare minnow larvae by abnormal behavior, energy metabolism and endoplasmic reticulum stress. Chem Biol Interact 227:32-36

Lopes-dos-Santos RMA, Galante-Oliveira S, Lopes E, Almeida C, Barroso C (2014) Assessment of imposex and butyltin concentrations in Gemophos viverratus (Kiener, 1834), from Sao Vicente, Republic of Cabo Verde (Africa). Environ Sci Pollut R 21:10671-10677

Ma H, Dai S, Huang G (2000) Distribution of tributyltin chloride in laboratory simulated estuarine microcosms. Water Res 34:2829-2841

Matthiessen P, Gibbs PE (1998) Critical appraisal of the evidence for tributyltin-mediated endocrine disruption in mollusks. Environ Toxicol Chem 17:37-43

Meador JP (1986) An analysis o photobehavior o Daphnia magna exposed to tributyltin. In: Proceedings of the Organotin Symposium. Oceans' 86. Institute of Electrical and Electronics Engineers, Washington, D.C., 1213

Meador JP, Krone CA, Dyer DW, Varanasi U (1997) Toxicity of sedimentassociated tributyltin to infaunal invertebrates: species comparison and the role of organic carbon. Mar Environ Res 43:219-241 
Nielsen JB, Strand J (2002) Butyltin compounds in human liver. Environ Res 88:129-133

Ni N, El-Sayed MM, Sanghvi T, Yalkowsky SH (2000) Estimation of the effect of $\mathrm{NaCl}$ on the solubility of organic compounds in aqueous solutions. J Pharm Sci 89:1620-1625

Novelli AA, Argese E, Tagliapietra D, Bettiol C, Ghirardini AV (2002) Toxicity of tributyltin and triphenyltin to early life-stages of Paracentrotus lividus (Echinodermata: Echinoidea). Environ Toxicol Chem 21:859-864

O'Loughlin EJ, Traina SJ, Chin YP (2000) Association of organotin compounds with aquatic and terrestrial humic substances. Environ Toxicol Chem 19:2015-2021

Paz-Villarraga CA, Castro ÍB, Miloslavich P, Fillmann G (2015) Venezuelan Caribbean Sea under the threat of TBT. Chemosphere 119:704-710

Peter C (2003) Organometallic compounds in the environment. John Wiley \& Sons Ltd., Chichester

Quintas PY, Oliva AL, Arias A, Domini CE, Alvarez MB, Garrido M, Marcovecchio JE (2016) Seasonal changes in organotin compounds in sediments from the Bahia Blanca Estuary. Environ Earth Sci 75: $659-672$

Randall L, Weber JH (1986) Adsorptive behavior of butyltin compounds under simulated estuarine conditions. Sci Total Environ 57:191-203

Roberts MH (1987) Acute toxicity of tributyltin chloride to embryos and larvae of two bivalve mollusks Crassstra virginica and Mercenaria mercenaria. Bull Environ Contam Toxicol 39:1012-1019

Ruiz JM, Barreiro R, Couceiro L, Quintela M (2008) Decreased TBT pollution and changing bioaccumulation pattern in gastropods imply butyltin desorption from sediments. Chemosphere 73:1253-1257

Ruppert K, Geiss C, Ostermann S, Theis C, Oehlmann J (2016) Comparative sensitivity of juvenile and adult Potamopyrgus antipodarum (Mollusca: Hydrobiidae) under chronic exposure to cadmium and tributyltin. J Environ Sci Heal A 51:736-743

Sabah A, Bancon-Montigny C, Rodier C, Marchand P, Delpoux S, Ijjaali M, Tournou MG (2016) Occurrence and removal of butyltin compounds in a waste stabilisation pond of a domestic waste water treatment plant of a rural French town. Chemosphere 144:2497-2506

Sahoo TP, Oikari A (2016) Use of early life-stages of zebrafish to assess toxicity of sediments contaminated by organotin compounds. Soil Sediment Contam 25:117-132

Said-Pullicino D, Vella AJ (2005) Adsorption characteristics of tributyltin on municipal solid waste compost. Appl Organometal Chem 19:719-726

Sakultantimetha A, Keenan HE, Beattie TK, Bangkedphol S, Cavoura O (2011) Bioremediation of tributyltin contaminated sediment: degradation enhancement and improvement of bioavailability to promote treatment processes. Chemosphere 83:680-686

Seligman PF, Maguire RJ, Lee RF, Hinga KR, Balkirs AO, Stang PM (1996) Pressistence and fate of tributyltin on aqatic ecosystems. Environmental fate and effects. Chapman Hall, London

Shoukry MM (1996) Equilibrium studies of the diorganotin(IV) complexes with some amino acids and related compounds. Talanta 43:177-183
Shue MF, Chen TC, Bellotindos LM, Lu MC (2014) Tributyltin distribution and producing androgenic activity in water, sediment, and fish muscle. J Environ Sci Heal B 49:432-438

Sousa ACA, Pastorinho MR, Takahashi S, Tanabe S (2014) History on organotin compounds, from snails to humans. Environ Chem Lett 12:117-137

St-Louis R, Pelletier É, Marsot P (1997) A mechanistic approach to tributyltin (TBT) sorption by marine microflagellated alga Pavlova lutheri. Appl Organomet Chem 11:543-550

Strand J, Asmund G (2003) Tributyltin accumulation and effects in marine molluscs from West Greenland. Environ Pollut 123:31-37

Strand J, Jacobsen JA, Pedersen B, Granmo A (2003) Butyltin compounds in sediment and molluscs from the shipping strait between Denmark and Sweden. Environ Pollut 124:7-15

Strand J, Larsen MM, Lockyer C (2005) Accumulation of organotin compounds and mercury in harbour porpoises (Phocoena phocoena) from the Danish waters and West Greenland. Sci Total Environ 350:59-71

Stronkhorst J, van Hattum B, Bowmer T (1999) Bioaccumulation and toxicity of tributyltin to a burrowing heart urchin and an amphipod in spiked, silty marine sediments. Environ Toxicol Chem 18:2343-2351

Tang CH, Wang WH (2008) Butyltin accumulation in two marine bivalves along a pollution gradient. Environ Toxicol Chem 27:2179-2185

Tang CH, Wang WH (2009) Organotin accumulation in oysters and rock shells under field conditions. J Environ Monit 11:1601-1607

Unger MA, MacIntyre WG, Huggett RJ (1988) Sorption behavior of tributyltin on estuarine and freshwater sediments. Environ Toxicol Chem 7:907-915

Üveges M, Rodríguez-González P, García Alonso JI, Sanz-Medel A, Fodor P (2007) Isotope dilution analysis mass spectrometry for the routine measurement of butyltin compounds in marine environmental and biological samples. MICROCHEM J 85:115-121

Valkirs AO, Davidson BM, Seligman PF (1987) Sublethal growth effects and mortality to marine bivalves from long-term exposure to tributyltin. Chemosphere 16:201-220

Vighi M, Calamari D (1985) QSARs for organotin compounds on Daphnia magna. Chemosphere 14:1925-1932

Watanabe N, Takatsuki H, Sakai S (1997) Desorption of tributyltin, dibutyltin and zinc from resuspended sediment. Appl Organomet Chem 11:273-279

Weber WJ, Mcginley PM, Katz LE (1991) Sorption phenomena in subsurface systems - concepts, models and effects on contaminant fate and transport. Water Res 25:499-528

Weidenhaupt A, Arnold C, Muller SR, Haderlein SB, Schwarzenbach RP (1997) Sorption of organotin biocides to mineral surfaces. Environ Sci Technol 31:2603-2609

White JS, Tobin JM (2004) Inorganic tin and organotin interactions with Candida maltosa. Appl Microbiol Biotechnol 63:445-451

WHO (1990) Environmental health criteria for tributyltin compounds. In: Environmental health criteria, vol 116. World Health Organization, Geneve. http://www.inchem.org/documents/ehc/ehc/ehc116.htm 